\title{
CD4+CD25high Regulatory T Cells in the Developing Human Immune System: Implications for Pediatric HIV Infection Jakob Michaëlsson ${ }^{\dagger 1}$, Jeff E Mold ${ }^{\dagger 1}$, Joseph M McCune* ${ }^{* \neq 1,2,3}$ and Douglas F Nixon $1,2,3$
}

\author{
Address: ${ }^{1}$ Gladstone Institute of Virology and Immunology, University of California, San Francisco, CA 94158, USA, ${ }^{2}$ Department of Medicine, \\ University of California, San Francisco, CA 94110 USA and ${ }^{3}$ These authors are equal last authors \\ Email: Joseph M McCune* - mmccune@gladstone.ucsf.edu \\ * Corresponding author †Equal contributors $¥$ Presenting author
}

from 2005 International Meeting of The Institute of Human Virology

Baltimore, USA, 29 August - 2 September 2005

Published: 8 December 2005

Retrovirology 2005, 2(SuppI I):SI07 doi:I0.II86/1742-4690-2-SI-SI07

\section{Background}

Although human T cells enter the peripheral lymphoid tissues early during fetal development ${ }^{1}$, the adaptive immune system in the fetus has largely been regarded as functionally immature and unresponsive to stimulation. In adults, CD4CD25high regulatory T cells (TReg) are critical for maintenance of peripheral $\mathrm{T}$ cell tolerance, but their role in the developing fetus is unknown. Here, we demonstrate that a large population of human fetal FOXP3CD4CD25high TReg cells, present from the earliest stages of $\mathrm{T}$ cell colonization of the periphery, efficiently suppresses fetal $\mathrm{T}$ cell responses.

\section{Results}

Depletion of $\mathrm{CD} 4{ }^{+} \mathrm{CD} 25^{\text {high }} \mathrm{T}_{\text {Reg }}$ cells from fetal lymph node cells, but not adult lymph nodes, resulted in the proliferation and acquisition of effector functions in the absence of exogenous stimulation by a large subpopulation of $\mathrm{T}$ cells identifiable by the expression of CD69 in utero. A large population of fetal CD $4{ }^{+} \mathrm{CD} 25^{\text {high }} \mathrm{T}_{\text {Reg }}$ cells also expressed CD69+ and displayed a memory/effector phenotype, as indicated by low expression of CD45RA and CCR7. However, the CD69+ and CD69CD4 ${ }^{+} \mathrm{CD} 25^{\text {high }} \mathrm{T}_{\text {Reg }}$ cells did not differ in their suppression of $\mathrm{T}$ cell responses in the absence of exogenous stimulation, indicating that the activation status of these cells do not correlate with their suppressive function.

\section{Conclusion}

These studies demonstrate that the fetal T cells are, in the absence $\mathrm{CD} 4{ }^{+} \mathrm{CD} 25^{\text {high }} \mathrm{T}_{\text {Reg }}$ cells, highly responsive to stimulation, indicating that human fetal $\mathrm{T}$ cells are active and functionally mature. Strong evidence has also been obtained for an important role for $\mathrm{CD}^{+} \mathrm{CD} 25^{\text {high }} \mathrm{T}_{\mathrm{Reg}}$ cells in controlling $\mathrm{T}$ cell responses in utero. The implications of these findings for pediatric HIV infection will be discussed. 